\title{
Klasifikasi Wajah Hewan Mamalia Tampak Depan Menggunakan k-Nearest Neighbor Dengan Ekstraksi Fitur HOG
}

\author{
http://dx.doi.org/10.28932/jutisi.v5i1.918

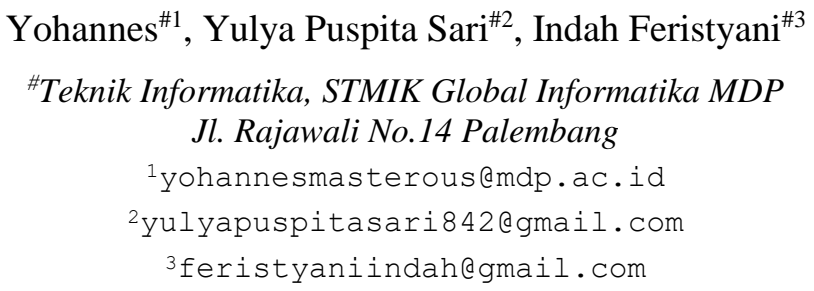

\begin{abstract}
Mammal is a type of animal that has many diverse characteristics, such as vertebrates and breastfeeding. In this study, the HOG feature and the k-NN method were proposed to classify 15 species of mammals. This study uses the LHIAnimal-Faces dataset which has fifteen species of mammals, where each type of mammal has 50 images measuring 100x100 pixels. The image will be conducted the process by the HOG feature extraction process and continued into the classification process using $k$-Nearest Neighbor. The performance of the HOG and k-NN features that get the best value is in deer and monkey, the best results for precision, recall, and accuracy are at $\mathrm{k}=3$ where $\mathrm{HOG}$ feature extraction provides good vector features to be used in the classification process using the k-NN method.
\end{abstract}

Keywords - Mammals, HOG, k-Nearest Neighbor, Euclidean Distance.

\section{Pendahuluan}

Hewan mamalia merupakan hewan vertebrata yang memiliki rambut di tubuhnya. Hewan mamalia dapat dinyatakan sebagai hewan bertulang belakang, berdarah panas, bernapas dengan paru-paru dan mempunyai neocortex pada otaknya. Hewan mamalia juga dikenal sebagai hewan yang berkembang biak dengan cara melahirkan, namun ada juga yang berkembang biak dengan cara bertelur. Mamalia memiliki banyak ciri yang beraneka ragam dari bentuk, warna, dan ukuran. Perbedaan tersebut dapat dilihat dari rambut yang ada di tubuhnya, dan dari bentuk karakteristiknya. Salah satu karakteristik hewan mamalia, yaitu dari bentuk wajah yang bisa digunakan sebagai pembeda dari setiap hewan mamalia.

Pada penelitian [1] telah dilakukan klasifikasi hewan menggunakan citra wajah menggunakan Convolutional Neural Network (CNN) dan Kernel Fisher Analysis (KFA) sebagai ekstraksi fiturnya dengan score-level fusion.
Penggunaan metode tersebut mampu untuk mengklasifikasi hewan mamalia berdasarkan fitur wajah [1].

Klasifikasi mengenai citra wajah juga dilakukan oleh Fandiansyah, Sari, dan Ningrum [2], yang membahas mengenai pengenalan wajah menggunakan metode Linear Discriminant Analysis dan k-Nearest Neighbor. Ada juga yang melakukan penelitian mengenai wajah manusia tetapi dengan metode yang berbeda, seperti penelitian yang dilakukan oleh Cahyaningtyas [3], pengenalan wajah menggunakan metode ekstraksi fitur Local Binary Pattern dan k-NN. Dengan menggunakan metode LBP dan k-NN didapatkan hasil yang kurang baik, dimana kesesuaian citra terjadi saat nilai $k$-nya rendah [3].

Metode k-NN tidak hanya digunakan untuk klasifikasi citra wajah saja tetapi untuk klasifikasi daun juga, seperti penelitian yang dilakukan oleh Liantoni [4], yang membahas tentang klasifikasi daun menggunakan metode k-NN. Tidak hanya metode $\mathrm{k}-\mathrm{NN}$ yang digunakan untuk klasifikasi tetapi metode Nä̈ve Bayes Classifier juga digunakan untuk mengklasifikasikan daun herbal yang dilakukan oleh Febri Liantoni [5].

Tidak hanya daun, metode k-NN dan GLCM juga sudah digunakan dalam klasifikasi batik yang dilakukan oleh Wijayanto [6]. Hasil dari dua metode tersebut didapatkan tingkat akurasi yang kurang baik, dimana tidak semua batik dapat terklasifikasikan dengan benar.

Selain pada citra wajah hewan, manusia, daun, dan batik. Metode k-NN juga dapat digunakan untuk klasifikasi kendaraan roda empat [7] dan pengenalan pola tekstur citra saliva untuk deteksi ovulasi [8].

Tidak hanya itu, metode Histogram of Oriented Gradient (HOG) juga bisa melakukan deteksi fitur yang hasil akhirnya dapat menghasilkan tingkat akurasi yang baik. Seperti penelitian yang telah dilakukan oleh Hafidhoh dan Sukmana [9], yang membahas tentang deteksi pemain basket terklasifikasi dengan metode HOG. Hasil dari penelitian 
tersebut dimana metode HOG mampu melakukan deteksi yang fokus hanya pada pemain sedangkan objek yang bukan non-pemain seperti wasit tidak dideteksi. Dari hasil pengujian yang telah dilakukan, metode k-NN dan HOG memiliki tingkat akurasi yang sangat baik.

Pada penelitian yang dilakukan oleh Palit [10], membahas tentang mengenali rambu lalu lintas. Penelitian tersebut menerapkan 2 (dua) metode, yaitu metode HOG dan k-NN. Dengan menggunakan metode HOG dan k-NN, hasil dari penelitian tersebut didapatkan tingkat akurasi yang bisa dikatakan sangat baik.

Metode k-NN dan HOG dapat juga diterapkan dalam pengujian tanda tangan, seperti yang dilakukan oleh Harfiya, Widodo, dan Wihandika [11]. Penelitian tersebut membahas tentang verifikasi citra tanda tangan berdasarkan ciri Pyramid Histogram of Oriented Gradient (PHOG) menggunakan metode klasifikasi k-NN. Hasilnya pada pengujian data tanda tangan asli metode k-NN bekerja dengan baik sebagai metode klasifikasi pada proses verifikasi tanda tangan.

Penelitian yang menggunakan ekstraksi ciri HOG juga digunakan untuk perbandingan jarak potret dan resolusi kamera pada tingkat akurasi pengenalan angka $\mathrm{kWh}$ meter menggunakan metode SVM, seperti yang dilakukan oleh Amputri [12], hasil dari penelitian ini memiliki tingkat akurasi yang cukup baik.

Melihat metode k-NN dan ekstraksi fitur HOG memiliki tingkat akurasi yang baik untuk mengenali warna serta bentuk dan metode klasifikasi k-NN baik dalam mengklasifikasikan objek, maka dilakukan penelitian untuk mengetahui performa metode HOG dan k-NN untuk klasifikasi wajah hewan mamalia tampak depan.

\section{LANDASAN TEORI}

\section{A. Mamalia}

Mamalia adalah hewan yang memiliki rambut di tubuhnya, bertulang belakang, menyusui dan dikenal berkembang biaknya dengan cara melahirkan, walaupun tidak semua hewan mamalia berkembang biak dengan cara melahirkan. Hewan mamalia juga ada yang berkembang biak dengan cara bertelur seperti hewan mamalia platypus. Hewan mamalia juga bernafas dengan paru-paru serta memiliki ruas tulang belakang sebanyak 7 (tujuh) ruas dan berambut serta memiliki anggota tubuh lengkap untuk berjalan, berenang atau lainnya. Mamalia juga mempunyai kuku yang panjang untuk menangkap makanan.

\section{B. Histogram of Oriented Histogram (HOG)}

HOG merupakan bentuk dari local objek dan nilai yang digunakan dari intensitas gradien untuk mengekstraksi fitur yang digunakan pada computer vision dan image processing. HOG memiliki keunggulan, yaitu mampu menangkap tepi atau struktur gradient yang sangat karakteristik dari bentuk sebenarnya [13]. Tiap image mempunyai karakteristik yang ditunjukkan oleh distribusi gradient. Karakteristik tersebut diperoleh dengan membagi image ke dalam daerah kecil yang disebut cell. Proses HOG memilki tahapan antara lain:

1. Melakukan konversi citra.

Untuk mengubah sebuah citra RGB menjadi citra grayscale secara umum digunakan persamaan (1).

Grayscale $=\frac{R+G+B}{3}$

Dimana :

$R=$ unsur warna merah.

$G=$ unsur warna hijau.

$B=$ unsur warna biru.

Nilai yang dihasilkan dari persamaan (1) diinput ke masing-masing unsur warna dasar citra grayscale.

2. Menghitung nilai gradient pada setiap pixel dalam citra grayscale.

Setelah mendapatkan citra grayscale, proses selanjutnya, yaitu membagi gambar menjadi wilayah kecil yang terhubung yang disebut sebagai cell. Nilai yang berbeda dikelompokkan dalam bentuk block dan cell. Nilai gradient pada setiap pixel dihitung menggunakan persamaan (2) dan (3).

$$
\begin{aligned}
& I x(\mathrm{r}, \mathrm{c})=\mathrm{I}(\mathrm{r}, \mathrm{c}+1)-\mathrm{I}(\mathrm{r}, \mathrm{c}-1) \\
& I y(\mathrm{r}, \mathrm{c})=\mathrm{I}(\mathrm{r}+1, \mathrm{c})-\mathrm{I}(\mathrm{r}-1, \mathrm{c})
\end{aligned}
$$

Dimana I merupakan image (citra) dan $r$ sebagai baris dan $c$ sebagai kolom dari citra. Setelah nilai $I x$ dan Iy telah diperoleh maka proses selanjutnya mencari besar gradient $\mu$ menggunakan persamaan (4).

$$
\mu=\sqrt{l x^{2}+l y^{2}}
$$

Setelah mendapatkan nilai $\mu$, proses selanjutnya adalah menentukan nilai orientasi $\theta$ menggunakan persamaan (5)

$$
\theta=\frac{180}{\pi}\left(\tan _{2}^{-1}(l y, l x) \bmod \pi\right)
$$

\section{Orientasi Binning}

Setelah mendapatkan nilai $\mu$ (besar gradient) dan nilai dari tiap blok, proses selanjutnya yaitu mencari nilai-nilai tiap orientasi sel histogram untuk nilai bin $j, C_{i}$ dan $w$ menggunakan persamaan (6), (7), dan (8). Sel dapat berupa dalam bentuk persegi panjang.

$$
\begin{aligned}
& w=\frac{180}{B} \\
& \operatorname{bin} j=\left[\frac{\theta}{w}-\frac{1}{2}\right] \bmod B
\end{aligned}
$$


Dengan batasan [wi,w(i+1)]

$$
C_{i}=W\left(i+\frac{1}{2}\right)
$$

Kemudian nilai vote bin yang didapatkan terbagi dua bagian, yaitu vote bin $V_{j}$ pada persamaan (9) dan vote bin $V_{j+1}$ pada persamaan (10) dimana nilai $B$ didapatkan dari jumlah bin yang ditentukan.

$$
\begin{aligned}
& V_{j}=\mu \frac{c_{j+1}-\theta}{w} \\
& V_{j+1}=\mu \frac{\theta-c_{j}}{w}
\end{aligned}
$$

4. Menormalisasikan nilai tiap bin orientasi

Ketika nilai dari bin orientasi telah didapatkan, proses selanjutnya melakukan blok normalisasi dimana fungsinya untuk mendapatkan nilai $b$ tiap blok untuk mengurangi terjadinya overlapping. Blok overlapping dapat dilihat pada Gambar 1. Normalisasi blok dihitung menggunakan persamaan (11).

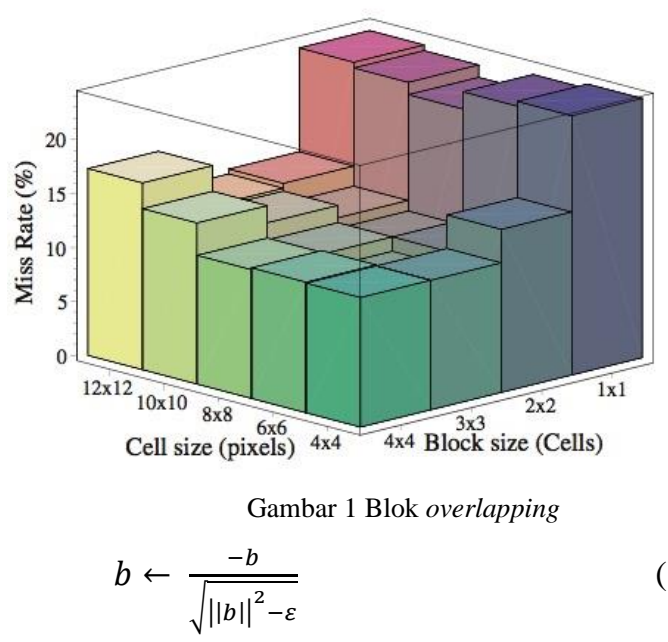

Alur proses Histogram of Oriented Gradient dapat dilihat pada Gambar 2.

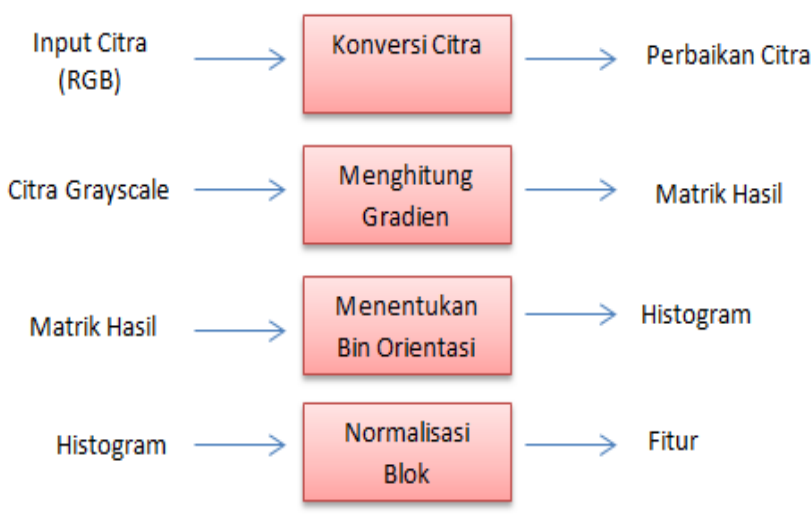

Gambar 2 Proses Histogram of Oriented Gradient

\section{C. $k$-Nearest Neighbor $(k$-NN)}

$K$-Nearest Neighbor merupakan salah satu algoritma yang berbasis pembelajaran. dimana data training disimpan, sehingga klasifikasi untuk data baru yang tidak diklasifikasi didapatkan dengan membandingkannya dengan data yang paling mirip dengan data training. Ada berbagai cara untuk mengukur jarak kedekatan antara data baru dengan data training, diantaranya menggunakan euclidean distance dan manhattan distance, tetapi yang paling sering digunakan adalah euclidean distance. Selain itu euclidean distance mempunyai hasil akurasi paling baik dibandingkan dengan manhattan distance. Adapun euclidean distance dapat dihitung [14] menggunakan persamaan (12).

$$
d(\mathrm{X}, \mathrm{Y})=\sqrt{\sum_{i=1}^{n}\left(a_{i}-b_{i}\right)^{2}}
$$

dimana :

$d(X, Y)=$ Jarak Euclidean yang akan dicari untuk mencari nilai kemiripan yang menghasilkan nilai paling kecil.

$a_{i}=$ nilai citra acuan yang telah disimpan

$b_{i} \quad=$ nilai citra uji

$n \quad=$ jumlah data citra

$$
i \quad=1,2,3, \ldots \ldots, \mathrm{n}
$$

Pada persamaan (12), $d$ adalah jarak skalar dari kedua vektor $X$ dan $Y$ dari matriks dengan ukuran $n$ dimensi. Pada fase training, algoritma ini hanya melakukan penyimpanan vektor-vektor fitur dan klasifikasi data training. Pada fase klasifikasi, fitur-fitur yang sama dihitung untuk testing data. Jarak dari vektor baru ini terhadap seluruh vektor training dihitung dan sejumlah $k$ buah yang paling dekat diambil. Titik yang baru klasifikasinya diprediksikan termasuk pada klasifikasi terbanyak dari titik- titik tersebut. Metode $k$ Nearest Neighbor memiliki tahapan sebagai berikut:

1. Menentukan parameter nilai $k$ (tetangga terdekat).

2. Menghitung euclidean distance.

3. Mengurutkan hasil dari perhitungan euclidean distance secara ascending.

4. Mengelompokkan hasil yang telah diurutkan ke dalam nilai $k$ yang telah ditentukan.

\section{Confusion Matrix}

Confusion matrix merupakan metode yang digunakan untuk mengukur kinerja suatu metode klasifikasi dalam hal membandingkan hasil klasifikasi yang dilakukan oleh sistem dengan hasil klasifikasi yang seharusnya (Solichin 2017). Alat ukur yang dapat digunakan dari confusion matrix adalah dengan menghitung persentase precision, recall, dan accuracy. Adapun cara menghitung dengan confusion matrix menggunakan persamaan (13), (14), dan (15).

$$
\begin{aligned}
& \text { Precision }=\frac{T P}{T P+F P} \\
& \text { Recall }=\frac{T P}{T P+F N}
\end{aligned}
$$


Accuracy $=\frac{T P+T N}{T P+T N+F P+F N}$

Keterangan :

$T P=$ Jumlah data positif citra hewan mamalia yang terklasifikasi dengan benar oleh sistem.

$T N=$ Jumlah data negatif citra hewan mamalia yang terklasifikasi dengan benar oleh sistem.

$F N=$ Jumlah data negatif citra hewan mamalia namun terklasifikasi salah oleh sistem.

$F P=$ Jumlah data positif citra hewan mamalia namun terklasifikasi salah oleh sistem

\section{METODOLOGI PENELITIAN}

\section{A. Metodologi}

Metodologi yang digunakan untuk melakukan penelitian sebagai berikut. Rancangan metodologi dapat dilihat pada Gambar 3.

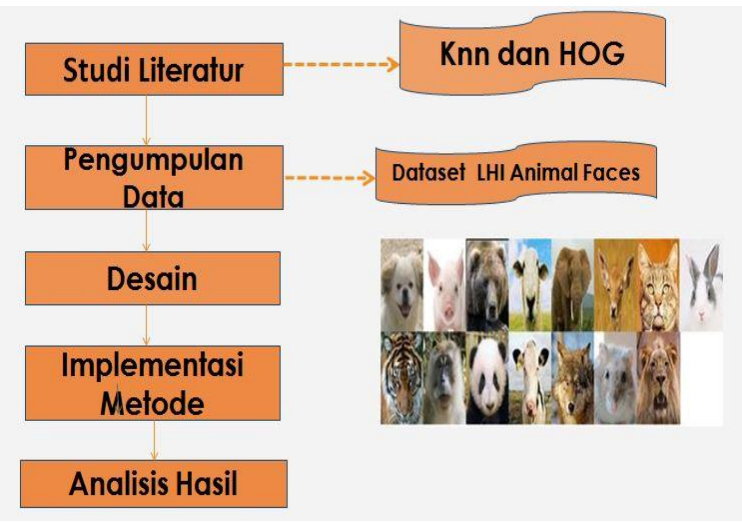

Gambar 3 Rancangan Metodologi

1. Studi Literatur

Pada tahapan ini dilakukan pengumpulan jurnal yang terkait dengan pengenalan ekstraksi fitur HOG serta menggunakan metode k-NN.

2. Pengumpulan Data

Pada tahapan pengumpulan data, didapatkan Dataset yang akan diolah dalam penelitian ini yaitu LHI-Animal-Faces Dataset oleh Information Projection yang terdiri dari 19 jenis hewan diantaranya 15 jenis hewan mamalia dan 4 jenis wajah hewan unggas. Dataset ini juga digunakan oleh penelitian mamalia yang menggunakan pendekatan yang berbeda [14]. Dataset yang akan digunakan dalam penelitian ini hanya 15 jenis hewan mamalia (tidak termasuk dataset unggas) dimana setiap jenis hewan mamalia masing-masing diambil 50 citra wajah hewan mamalia.

3. Perancangan Metode

Pada tahapan ini akan ditetapkan metode yang akan digunakan, yaitu metode k-Nearest Neighbor (k-
NN) dan Histogram of Oriented Gradients (HOG) sebagai klasifikasi Wajah hewan mamalia.

4. Implementasi Metode

Pada tahapan ini terdapat dua fase yaitu fase training dan fase testing dimana fase-fase tersebut bertujuan untuk menguji tingkat akurasi dari metode k-NN dan HOG. Data yang dipakai untuk fase training dan testing berjumlah 750 citra dari 15 jenis hewan mamalia (tidak termasuk dataset unggas), dimana persentase pembagiannya $70 \%$ dan $30 \%$, yaitu 525 citra wajah hewan mamalia untuk data fase training dan 225 data citra wajah hewan mamalia untuk fase testing. Fase-fase tersebut dapat dilihat pada Gambar 4.

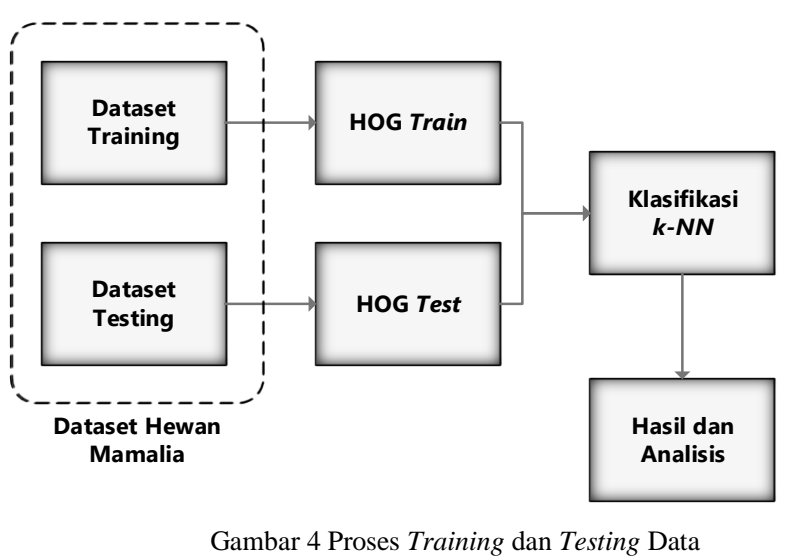

A. Fase Training Data

Pada tahap ini akan dilakukan proses training menggunakan dataset LHI-Animal-Faces dimana pada fase training ada 525 citra yang akan proses menggunakan ekstraksi fitur HOG untuk mendapatkan sebuah nilai fitur, dimana nilai fitur tersebut dilanjutkan ke proses klasifikasi menggunakan metode $\mathrm{k}-\mathrm{NN}$ training.

\section{B. Fase Testing Data}

Pada tahap testing skenario yang dibutuhkan sama seperti fase training yaitu menggunakan dataset LHI-Animal-Faces, dimana pada fase testing ada sebanyak 225 citra yang akan diekstraksi fiturnya menggunakan HOG, kemudian dilanjutkan dengan proses klasifikasi menggunakan metode k-NN testing, pada proses klasifikasi dilakukan 4 (empat) kali pengujian, yaitu $\mathrm{k}=3, \mathrm{k}=5$, $\mathrm{k}=7$ dan $\mathrm{k}=9$.

5. Analisis Hasil

Analisis hasil ini dilakukan untuk mengetahui performa klasifikasi wajah hewan mamalia dengan metode k-NN. Pada tahapan ini digunakan perhitungan confusion matrix untuk mencari nilai 
precision, recall, dan accuracy. Adapun cara menghitung dengan confusion matrix menggunakan persamaan (13), (14), dan (15).

\section{HASIL DAN PEMBAHASAN}

\section{A. Implementasi Ekstraksi Fitur HOG}

Pada tahapan ini dilakukan ekstraksi fitur HOG citra latih dan citra uji. Pada proses ini, dilakukan resize yang berukuran 100x100 pixel. Setelah melakukan resize data sebanyak 750 citra, kemudian citra hewan diubah dari citra RGB ke citra grayscale. Dari citra grayscale berukuran 100x100 maka didapatkan nilai Gx dan nilai Gy, setelah mendapatkan nilai Gx dan Gy didapatkan nilai magnitude dan orientasi binning. Tahap HOG dapat dilihat pada Gambar 5.

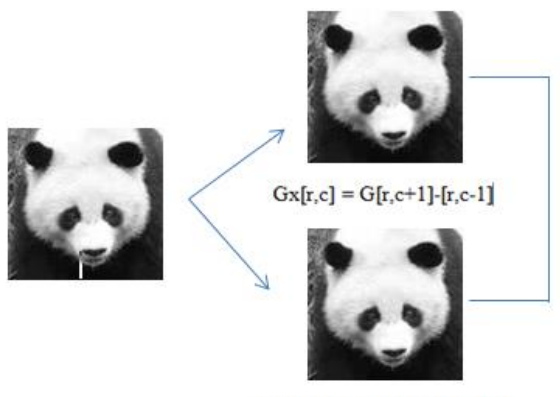

$\mathrm{Gy}[\mathrm{r}, \mathrm{c}]=\mathrm{G}[\mathrm{r}+1, \mathrm{c}]-[\mathrm{r}-1, \mathrm{c}]$

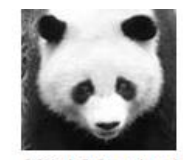

Nilai Magnitude

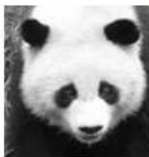

Nilai Orientasi Binning $\theta=\frac{180}{\pi}\left(\tan _{2}^{-1}\right)\left(l_{y}, l_{x}\right) \bmod$
Gambar 5 Tahap HOG

Langkah pertama, yaitu mengubah citra menjadi cell berukuran [8 8] pixel dengan block berukuran [2 2], karena ukuran citra adalah [100 100] maka jumlah cell yang didapatkan adalah $12 \times 12$ dan jumlah block yang didapatkan adalah $11 \times 11$ pixel. Jadi, terdapat 121 block, dengan cell berukuran [2 2] pixel $=4$ cell dan berisi 9 bin pada setiap block, 121 block $* 4$ cell $* 9$ bin $=4.356$ sehingga didapatkan fitur berukuran 1x4.356.

Setelah mendapatkan nilai feature vector maka dilakukan perhitungan untuk mendapatkan nilai vote dari setiap cell yang diawali dengan mencari nilai bobot (w) kemudian menghitung bin $j$ untuk menentukan batasan dari setiap cell yang dapat dilihat pada Gambar 6. Selanjutnya dilakukan perhitungan nilai vote. Hasil visualisasi ekstraksi citra hewan mamalia dapat dilihat pada Gambar 7.

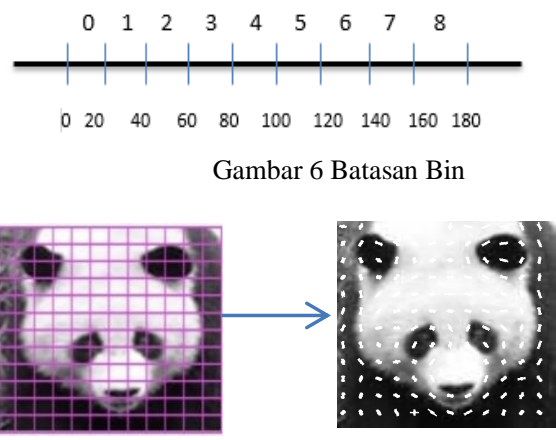

Gambar 7 Ekstraksi Hewan Mamalia

\section{B. Implementasi Metode $k-N N$}

Pada Pada tahapan ini, dilakukan proses klasifikasi k-NN dilakukan 4 kali pengujian, yaitu pada $\mathrm{k}=3, \mathrm{k}=5, \mathrm{k}=7$ dan $\mathrm{k}=9$ untuk mencari nilai precision, recall, dan accuracy dari setiap jenis hewan mamalia. Hasil confusion matrix klasifikasi wajah mamalia dapat dilihat pada Tabel I sampai IV.

TABEL I

CONFUSION MATRIX KLASIFIKASI WAJAH HEWAN MAMALIA UNTUK K = 3

\begin{tabular}{|c|c|c|c|c|c|c|c|c|c|c|c|c|c|c|c|}
\hline & Sapi & Rusa & Monyet & Tikus & Babi & Kelinci & Macan & Serigala & Gajah & Panda & Beruang & Kucing & Anjing & Singa & Domba \\
\hline Sapi & 12 & 2 & 1 & 0 & 0 & 0 & 0 & 0 & 0 & 0 & 0 & 0 & 0 & 0 & 0 \\
\hline Rusa & 0 & 15 & 0 & 0 & 0 & 0 & 0 & 0 & 0 & 0 & 0 & 0 & 0 & 0 & 0 \\
\hline Monyet & 0 & 0 & 15 & 0 & 0 & 0 & 0 & 0 & 0 & 0 & 0 & 0 & 0 & 0 & 0 \\
\hline Tikus & 0 & 0 & 10 & 4 & 0 & 0 & 0 & 0 & 0 & 0 & 1 & 0 & 0 & 0 & 0 \\
\hline Babi & 2 & 0 & 1 & 5 & 2 & 0 & 0 & 2 & 1 & 0 & 2 & 0 & 0 & 0 & 0 \\
\hline Kelinci & 0 & 4 & 3 & 0 & 0 & 7 & 0 & 1 & 0 & 0 & 0 & 0 & 0 & 0 & 0 \\
\hline Macan & 0 & 0 & 3 & 1 & 0 & 0 & 11 & 0 & 0 & 0 & 0 & 0 & 0 & 0 & 0 \\
\hline Serigala & 0 & 0 & 1 & 0 & 0 & 0 & 0 & 14 & 0 & 0 & 0 & 0 & 0 & 0 & 0 \\
\hline Gajah & 0 & 0 & 3 & 0 & 0 & 0 & 0 & 0 & 11 & 0 & 1 & 0 & 0 & 0 & 0 \\
\hline Panda & 0 & 0 & 1 & 2 & 0 & 0 & 0 & 0 & 0 & 10 & 2 & 0 & 0 & 0 & 0 \\
\hline Beruang & 0 & 0 & 1 & 0 & 0 & 0 & 0 & 0 & 0 & 0 & 14 & 0 & 0 & 0 & 0 \\
\hline Kucing & 0 & 0 & 1 & 0 & 0 & 0 & 0 & 1 & 0 & 0 & 1 & 12 & 0 & 0 & 0 \\
\hline Anjing & 0 & 0 & 5 & 1 & 0 & 0 & 0 & 0 & 0 & 0 & 7 & 0 & 2 & 0 & 0 \\
\hline Singa & 0 & 0 & 7 & 0 & 0 & 0 & 1 & 0 & 0 & 0 & 1 & 0 & 0 & 6 & 0 \\
\hline Domba & 0 & 8 & 1 & 1 & 0 & 1 & 0 & 0 & 0 & 0 & 0 & 0 & 0 & 0 & 4 \\
\hline
\end{tabular}


Berdasarkan Tabel I, pada kolom yang diberi warna secara diagonal menunjukkan nilai $\mathrm{TP}$ dari setiap jenis hewan pada percobaan $\mathrm{k}=3$. Untuk jenis hewan yang mendapatkan nilai TP yang paling baik diperoleh oleh Sapi, Rusa, Monyet, Macan, Serigala, Gajah, Panda, Beruang, dan Kucing yang nilainya mencapai 10 atau lebih.

TABEL II

CONFUSION MATRIX KLASIFIKASI WAJAH HEWAN MAMALIA UNTUK K = 5

\begin{tabular}{|c|c|c|c|c|c|c|c|c|c|c|c|c|c|c|c|}
\hline & Sapi & Rusa & Monyet & Tikus & Babi & Kelinci & Macan & Serigala & Gajah & Panda & Beruang & Kucing & Anjing & Singa & Domba \\
\hline Sapi & 8 & 4 & 2 & 0 & 0 & 0 & 0 & 0 & 1 & 0 & 0 & 0 & 0 & 0 & 0 \\
\hline Rusa & 0 & 14 & 0 & 0 & 0 & 0 & 0 & 1 & 0 & 0 & 0 & 0 & 0 & 0 & 0 \\
\hline Monyet & 0 & 0 & 14 & 0 & 0 & 0 & 0 & 0 & 0 & 0 & 1 & 0 & 0 & 0 & 0 \\
\hline Tikus & 0 & 0 & 8 & 2 & 0 & 0 & 0 & 2 & 1 & 0 & 2 & 0 & 0 & 0 & 0 \\
\hline Babi & 2 & 0 & 4 & 1 & 3 & 1 & 0 & 0 & 1 & 0 & 2 & 0 & 0 & 1 & 0 \\
\hline Kelinci & 0 & 3 & 1 & 0 & 0 & 8 & 0 & 3 & 0 & 0 & 0 & 0 & 0 & 0 & 0 \\
\hline Macan & 0 & 0 & 3 & 0 & 0 & 0 & 12 & 0 & 0 & 0 & 0 & 0 & 0 & 0 & 0 \\
\hline Serigala & 0 & 0 & 1 & 0 & 0 & 0 & 0 & 14 & 0 & 0 & 0 & 0 & 0 & 0 & 0 \\
\hline Gajah & 0 & 0 & 1 & 0 & 0 & 0 & 0 & 0 & 13 & 0 & 1 & 0 & 0 & 0 & 0 \\
\hline Panda & 0 & 0 & 2 & 0 & 0 & 0 & 0 & 1 & 0 & 9 & 3 & 0 & 0 & 0 & 0 \\
\hline Beruang & 0 & 0 & 0 & 0 & 0 & 0 & 0 & 1 & 0 & 0 & 14 & 0 & 0 & 0 & 0 \\
\hline Kucing & 0 & 0 & 0 & 0 & 0 & 0 & 0 & 1 & 0 & 0 & 1 & 13 & 0 & 0 & 0 \\
\hline Anjing & 0 & 0 & 3 & 1 & 0 & 0 & 0 & 0 & 0 & 0 & 7 & 0 & 3 & 1 & 0 \\
\hline Singa & 0 & 0 & 6 & 0 & 0 & 0 & 0 & 0 & 0 & 0 & 2 & 0 & 0 & 7 & 0 \\
\hline Domba & 0 & 7 & 3 & 0 & 0 & 1 & 0 & 0 & 0 & 0 & 0 & 0 & 0 & 0 & 4 \\
\hline
\end{tabular}

Berdasarkan Tabel II, pada kolom yang diberi warna secara diagonal menunjukkan nilai TP dari setiap jenis hewan pada percobaan $\mathrm{k}=5$. Untuk jenis hewan yang mendapatkan nilai TP yang paling baik diperoleh oleh Rusa, Monyet, Macan, Serigala, Gajah, Beruang, dan Kucing yang nilainya mencapai 10 atau lebih.

TABEL III

CONFUSION MATRIX KLASIFIKASI WAJAH HEWAN MAMALIA UNTUK K $=7$

\begin{tabular}{|l|c|c|c|c|c|c|c|c|c|c|c|c|c|c|c|}
\cline { 2 - 16 } \multicolumn{1}{l|}{} & Sapi & Rusa & Monyet & Tikus & Babi & Kelinci & Macan & Serigala & Gajah & Panda & Beruang & Kucing & Anjing & Singa & Domba \\
\hline Sapi & 7 & 1 & 3 & 0 & 0 & 0 & 0 & 1 & 2 & 0 & 0 & 0 & 0 & 0 & 1 \\
\hline Rusa & 0 & 15 & 0 & 0 & 0 & 0 & 0 & 0 & 0 & 0 & 0 & 0 & 0 & 0 & 0 \\
\hline Monyet & 0 & 0 & 14 & 0 & 0 & 0 & 0 & 0 & 0 & 0 & 1 & 0 & 0 & 0 & 0 \\
\hline Tikus & 0 & 0 & 7 & 1 & 0 & 0 & 0 & 5 & 1 & 0 & 1 & 0 & 0 & 0 & 0 \\
\hline Babi & 1 & 4 & 2 & 2 & 2 & 0 & 0 & 0 & 0 & 0 & 3 & 1 & 0 & 0 & 0 \\
\hline Kelinci & 0 & 4 & 2 & 0 & 0 & 6 & 0 & 3 & 0 & 0 & 0 & 0 & 0 & 0 & 0 \\
\hline Macan & 0 & 0 & 3 & 0 & 0 & 0 & 12 & 0 & 0 & 0 & 0 & 0 & 0 & 0 & 0 \\
\hline Serigala & 0 & 0 & 0 & 0 & 0 & 0 & 0 & 14 & 0 & 0 & 1 & 0 & 0 & 0 & 0 \\
\hline Gajah & 0 & 0 & 0 & 0 & 0 & 0 & 0 & 0 & 14 & 0 & 1 & 0 & 0 & 0 & 0 \\
\hline Panda & 0 & 0 & 2 & 0 & 0 & 0 & 0 & 1 & 0 & 5 & 7 & 0 & 0 & 0 & 0 \\
\hline Beruang & 0 & 0 & 0 & 0 & 0 & 0 & 0 & 0 & 0 & 0 & 15 & 0 & 0 & 0 & 0 \\
\hline Kucing & 0 & 0 & 0 & 0 & 0 & 0 & 0 & 1 & 0 & 0 & 1 & 13 & 0 & 0 & 0 \\
\hline Anjing & 0 & 0 & 6 & 0 & 0 & 0 & 1 & 0 & 0 & 0 & 6 & 0 & 2 & 0 & 0 \\
\hline Singa & 0 & 0 & 5 & 0 & 0 & 0 & 0 & 0 & 0 & 0 & 1 & 0 & 0 & 9 & 0 \\
\hline Domba & 1 & 7 & 2 & 0 & 0 & 0 & 0 & 0 & 0 & 0 & 0 & 0 & 0 & 0 & 5 \\
\hline
\end{tabular}

Berdasarkan Tabel III, pada kolom yang diberi warna secara diagonal menunjukkan nilai TP dari setiap jenis hewan pada percobaan $\mathrm{k}=7$. Untuk jenis hewan yang mendapatkan nilai TP yang paling baik diperoleh oleh Rusa, Monyet, Macan, Serigala, Gajah, Beruang, dan Kucing yang nilainya mencapai 10 atau lebih. 
TABEL IV

CONFUSION MATRIX KLASIFIKASI WAJAH HEWAN MAMALIA UNTUK K $=9$

\begin{tabular}{|l|c|c|c|c|c|c|c|c|c|c|c|c|c|c|c|}
\cline { 2 - 15 } \multicolumn{1}{l|}{} & Sapi & Rusa & Monyet & Tikus & Babi & Kelinci & Macan & Serigala & Gajah & Panda & Beruang & Kucing & Anjing & Singa & Domba \\
\hline Sapi & 8 & 3 & 2 & 0 & 0 & 0 & 0 & 1 & 1 & 0 & 0 & 0 & 0 & 0 & 0 \\
\hline Rusa & 0 & 14 & 0 & 0 & 0 & 0 & 0 & 1 & 0 & 0 & 0 & 0 & 0 & 0 & 0 \\
\hline Monyet & 0 & 0 & 14 & 0 & 0 & 0 & 0 & 0 & 0 & 0 & 1 & 0 & 0 & 0 & 0 \\
\hline Tikus & 0 & 0 & 6 & 2 & 0 & 0 & 0 & 4 & 1 & 0 & 2 & 0 & 0 & 0 & 0 \\
\hline Babi & 2 & 3 & 1 & 1 & 2 & 0 & 0 & 0 & 1 & 0 & 5 & 0 & 0 & 0 & 0 \\
\hline Kelinci & 0 & 3 & 1 & 0 & 0 & 7 & 0 & 3 & 0 & 0 & 1 & 0 & 0 & 0 & 0 \\
\hline Macan & 0 & 0 & 3 & 0 & 0 & 0 & 12 & 0 & 0 & 0 & 0 & 0 & 0 & 0 & 0 \\
\hline Serigala & 0 & 0 & 1 & 0 & 0 & 0 & 0 & 13 & 0 & 0 & 1 & 0 & 0 & 0 & 0 \\
\hline Gajah & 0 & 0 & 1 & 0 & 0 & 0 & 0 & 0 & 13 & 0 & 1 & 0 & 0 & 0 & 0 \\
\hline Panda & 0 & 0 & 1 & 0 & 0 & 0 & 0 & 2 & 0 & 6 & 6 & 0 & 0 & 0 & 0 \\
\hline Beruang & 0 & 0 & 0 & 0 & 0 & 0 & 0 & 0 & 0 & 0 & 15 & 0 & 0 & 0 & 0 \\
\hline Kucing & 0 & 0 & 1 & 0 & 0 & 0 & 0 & 1 & 0 & 0 & 0 & 13 & 0 & 0 & 0 \\
\hline Anjing & 0 & 0 & 6 & 0 & 0 & 0 & 1 & 0 & 0 & 0 & 6 & 0 & 1 & 1 & 0 \\
\hline Singa & 0 & 0 & 5 & 0 & 0 & 0 & 0 & 0 & 0 & 0 & 2 & 0 & 0 & 8 & 0 \\
\hline Domba & 1 & 7 & 2 & 0 & 0 & 1 & 0 & 0 & 0 & 0 & 0 & 0 & 0 & 0 & 4 \\
\hline
\end{tabular}

Berdasarkan Tabel IV, pada kolom yang diberi warna secara diagonal menunjukkan nilai $\mathrm{TP}$ dari setiap jenis hewan pada percobaan $\mathrm{k}=9$. Untuk jenis hewan yang mendapatkan nilai TP yang paling baik diperoleh oleh Rusa,

\section{Hasil Perhitungan Precision, Recall, dan Accuracy Setiap Hewan Mamalia}

Untuk Sapi hasil dari perhitungan precision nilai tertinggi diperoleh oleh $\mathrm{k}=3$ dengan perolehan nilai 0,86 untuk nilai terendah didapatkan oleh $\mathrm{k}=7$ dengan perolehan nilai 0,73 . Untuk penilaian recall tertinggi dicapai oleh $\mathrm{k}=3$ dengan hasil 0,8 dan terendah didapatkan oleh $\mathrm{k}=9$ dengan hasil 0,47 . Untuk accuracy perolehan rata-rata diatas 0,9 untuk $\mathrm{k}=3, \mathrm{k}=5, \mathrm{k}=7$, dan $\mathrm{k}=9$. Hasil tersebut bisa dilihat pada Gambar 8.

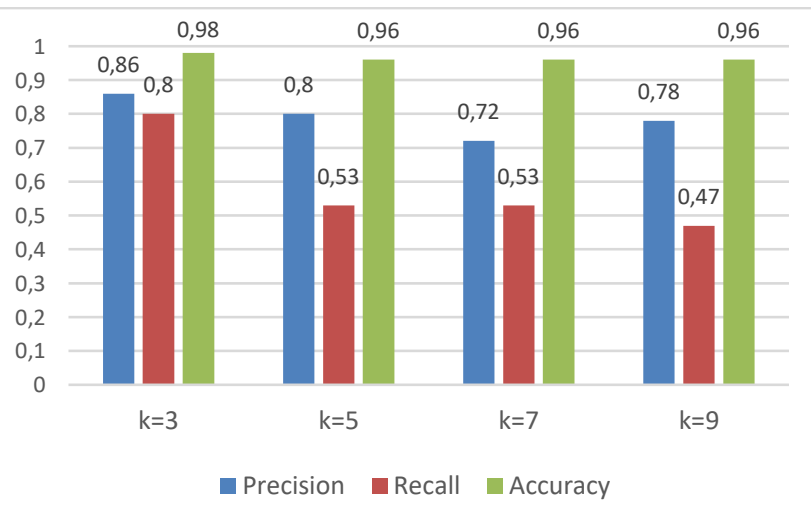

Gambar 8 Grafik Precision, Recall dan Accuracy untuk Klasifikasi Sapi

Untuk Rusa didapatkan hasil precision yaitu nilai tertinggi diperoleh oleh $\mathrm{k}=3$ dengan perolehan nilai 0,51
Monyet, Macan, Serigala, Gajah, Beruang, dan Kucing yang nilainya mencapai lebih dari 10 (sepuluh) yang terdeteksi sesuai dengan dataset.

untuk nilai terendah didapatkan oleh $\mathrm{k}=7$ dengan perolehan nilai 0,46 . Untuk recall nilai tertinggi dicapai oleh $\mathrm{k}=3$ dan $\mathrm{k}$ $=9$ dengan hasil 1 dan terendah didapatkan oleh $\mathrm{k}=5$ dengan hasil 0,93. Untuk accuracy perolehan rata-rata diatas 0,9 untuk $\mathrm{k}=3, \mathrm{k}=5, \mathrm{k}=7$, dan $\mathrm{k}=9$. Hasil tersebut bisa dilihat pada Gambar 9.

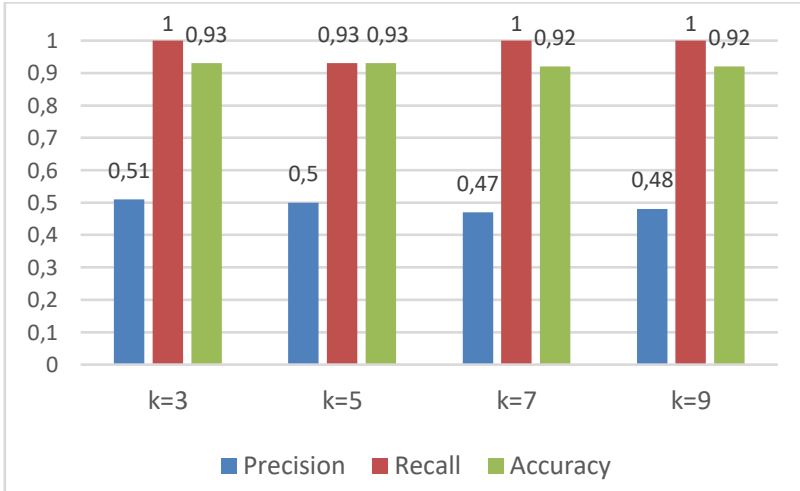

Gambar 9 Grafik Precision, Recall dan Accuracy untuk Klasifikasi Rusa

Untuk Monyet didapatkan hasil precision yaitu nilai tertinggi diperoleh oleh $\mathrm{k}=7$ dengan perolehan nilai 0,31 untuk nilai terendah didapatkan oleh $\mathrm{k}=3$ dengan perolehan nilai 0,28 . Untuk recall nilai tertinggi dicapai oleh $\mathrm{k}=3$ dengan hasil 1 dan terendah didapatkan oleh $\mathrm{k}=5, \mathrm{k}=7$ dan $\mathrm{k}=9$ dengan hasil 0,93 . Untuk accuracy perolehan rata-rata diatas 0,8 untuk $\mathrm{k}=3, \mathrm{k}=5, \mathrm{k}=7$, dan $\mathrm{k}=9$. Hasil tersebut bisa dilihat pada Gambar 10 . 


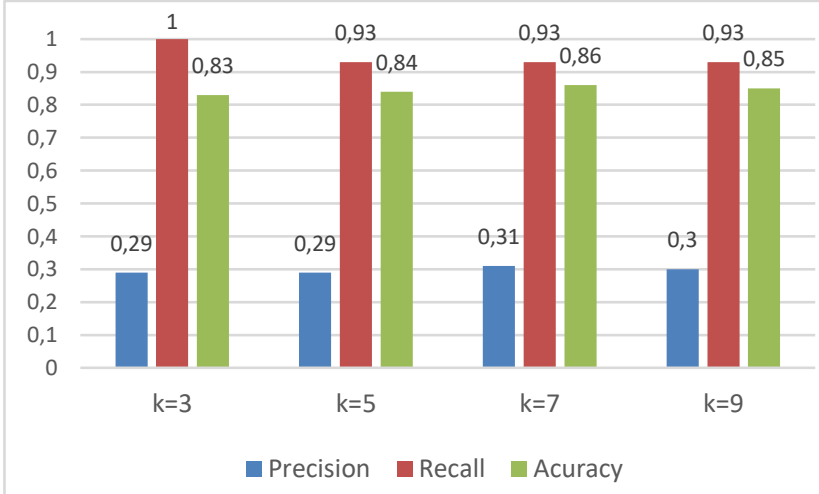

Gambar 10 Grafik Precision, Recall dan Accuracy untuk Klasifikasi Monyet

Untuk Tikus didapatkan hasil precision yaitu nilai tertinggi diperoleh oleh $\mathrm{k}=7$ dengan perolehan nilai 0,67 untuk nilai terendah didapatkan oleh $\mathrm{k}=3$ dengan perolehan nilai 0,26 . Untuk recall nilai tertinggi dicapai oleh $\mathrm{k}=3$ dengan hasil 0,28 dan terendah didapatkan oleh $\mathrm{k}=9$ dengan hasil 0,67 . Untuk accuracy perolehan rata-rata diatas 0,9 untuk $\mathrm{k}=3, \mathrm{k}=5, \mathrm{k}=7$, dan $\mathrm{k}=9$. Hasil tersebut bisa dilihat pada Gambar 11.

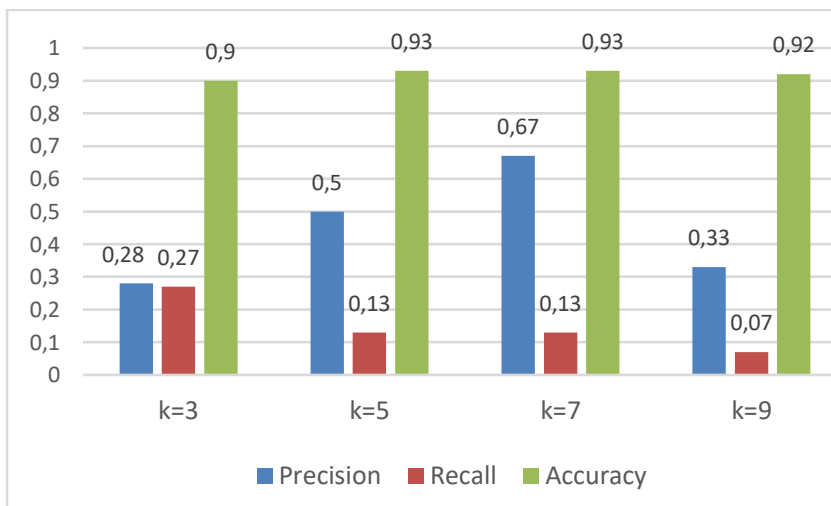

Gambar 11 Grafik Precision, Recall dan Accuracy untuk Klasifikasi Tikus

Untuk Babi didapatkan hasil precision yaitu nilai $\mathrm{k}=3$, $\mathrm{k}=5, \mathrm{k}=7$ dan $\mathrm{k}=9$ mendapatkan hasil yaitu 1 . Untuk perhitungan recall nilai tertinggi dicapai oleh $\mathrm{k}=5$ dengan hasil 0,2 dan terendah didapatkan oleh $k=3, k=7$ dan $k=9$ dengan hasil 0,13 . Untuk accuracy perolehan rata-rata diatas 0,9 untuk $\mathrm{k}=3, \mathrm{k}=5, \mathrm{k}=7$, dan $\mathrm{k}=9$. Hasil tersebut bisa dilihat pada Gambar 12.

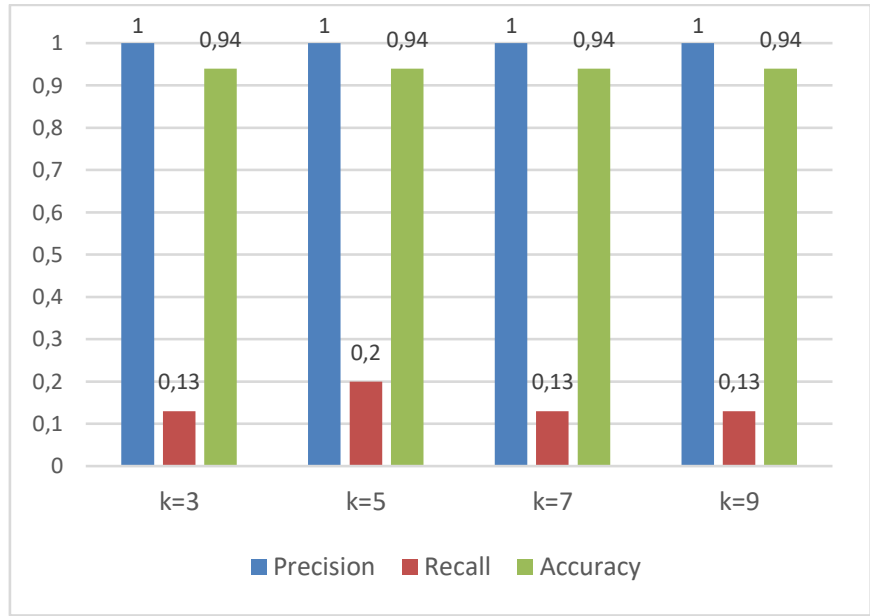

Gambar 12 Grafik Precision, Recall dan Accuracy untuk Klasifikasi Babi

Untuk Kelinci didapatkan hasil precision yaitu nilai tertinggi diperoleh oleh $\mathrm{k}=9$ dengan perolehan nilai 1 , untuk nilai terendah didapatkan oleh $\mathrm{k}=3, \mathrm{k}=5$ dan $\mathrm{k}=7$ dengan perolehan nilai 0,96 . Untuk recall nilai tertinggi dicapai oleh $\mathrm{k}=5$ dengan hasil 0,53 dan terendah didapatkan oleh $\mathrm{k}=9$ dengan hasil 0,4 . Untuk accuracy perolehan rata-rata diatas 0,9 untuk $\mathrm{k}=3, \mathrm{k}=5, \mathrm{k}=7$, dan $\mathrm{k}=9$. Hasil tersebut bisa dilihat pada Gambar 13.

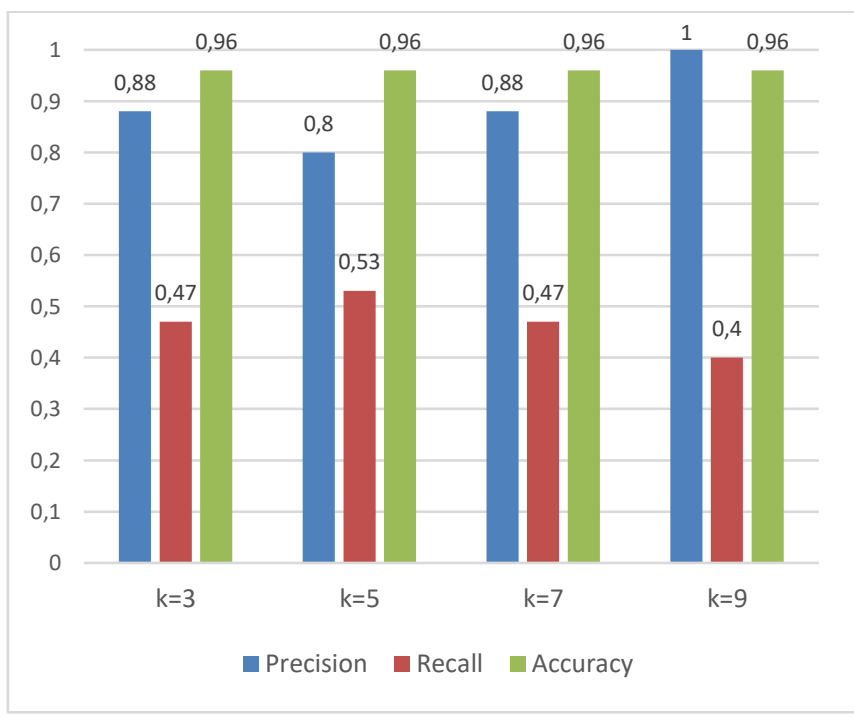

Gambar 13 Grafik Precision, Recall dan Accuracy untuk klasifikasi Kelinci

Untuk Macan didapatkan hasil precision yaitu nilai tertinggi diperoleh oleh $\mathrm{k}=5$ dengan perolehan nilai 1 , untuk nilai terendah didapatkan oleh $\mathrm{k}=3$ dengan perolehan nilai 0,91 . Untuk recall nilai tertinggi dicapai oleh $\mathrm{k}=5, \mathrm{k}=7$ dan $\mathrm{k}=9$ dengan hasil 0,8 dan terendah didapatkan oleh $\mathrm{k}=3$ dengan hasil 0,73. Untuk accuracy perolehan rata-rata diatas 
0,9 untuk $\mathrm{k}=3, \mathrm{k}=5, \mathrm{k}=7$, dan $\mathrm{k}=9$. Hasil tersebut bisa dilihat pada Gambar 14.

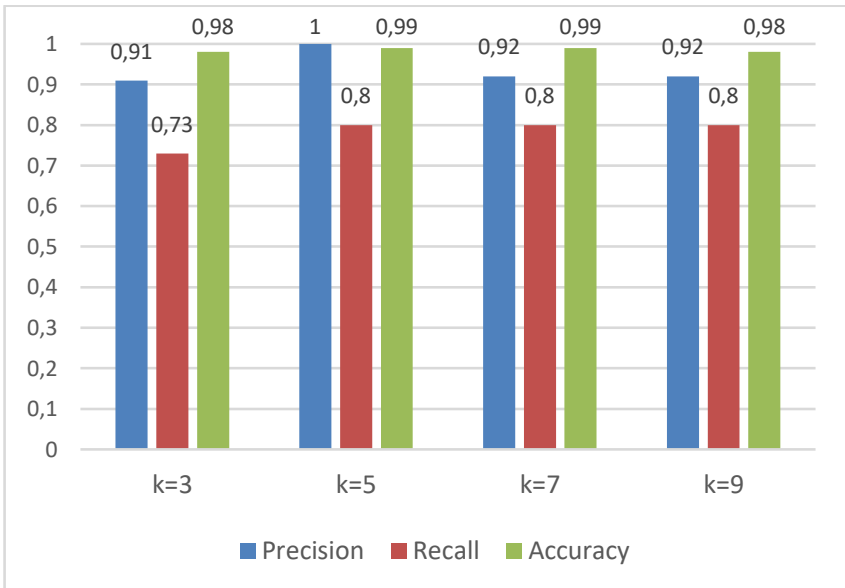

Gambar 14 Grafik Precision, Recall dan Accuracy untuk Klasifikasi Macan

Untuk Serigala didapatkan hasil precision yaitu nilai tertinggi diperoleh oleh $\mathrm{k}=9$ dengan perolehan nilai 0,93 untuk nilai terendah didapatkan oleh $\mathrm{k}=5$ dengan perolehan nilai 0,60 untuk recall nilai tertinggi dicapai oleh $\mathrm{k}=3$ dan $\mathrm{k}=7$ dengan hasil 0,93 dan terendah didapatkan oleh $\mathrm{k}=7$ dengan hasil 0,86 . Untuk accuracy perolehan rata-rata diatas 0,9 untuk $\mathrm{k}=3, \mathrm{k}=5, \mathrm{k}=7$, dan $\mathrm{k}=9$. Hasil tersebut bisa dilihat pada Gambar 15.

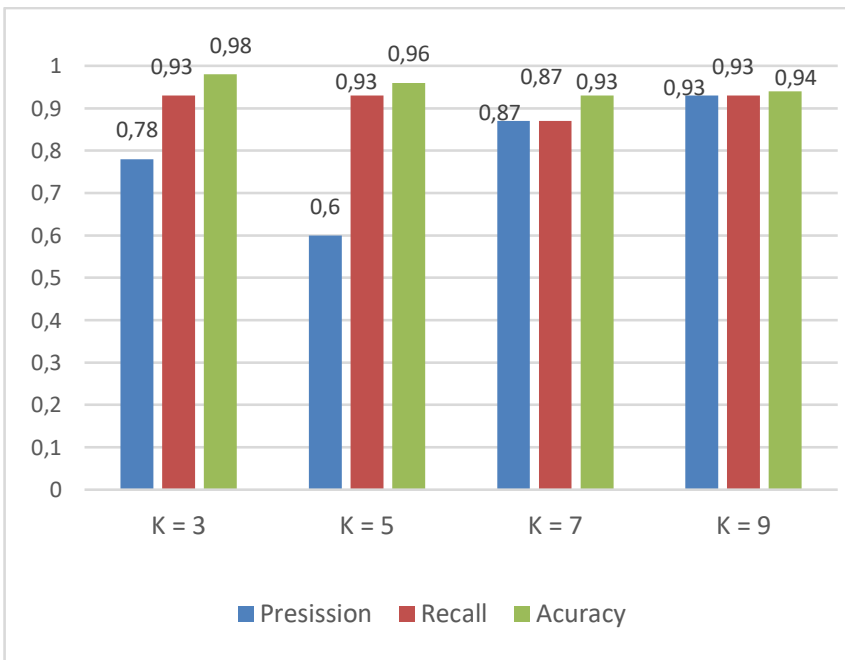

Gambar 15 Grafik Precision, Recall dan Accuracy untuk Klasifikasi Serigala

Untuk Gajah didapatkan hasil precision yaitu nilai tertinggi diperoleh oleh $\mathrm{k}=3$ dengan perolehan nilai 0,98 untuk nilai terendah didapatkan oleh $\mathrm{k}=5$ dan $\mathrm{k}=7$ dengan perolehan nilai 0,80 . Untuk recall nilai tertinggi dicapai oleh $\mathrm{k}=9$ dengan hasil 0,93 dan terendah didapatkan oleh $\mathrm{k}=3$ dengan hasil 0,73. Untuk accuracy perolehan rata-rata diatas
0,9 untuk $\mathrm{k}=3, \mathrm{k}=5, \mathrm{k}=7$, dan $\mathrm{k}=9$. Hasil tersebut bisa dilihat pada Gambar 16.

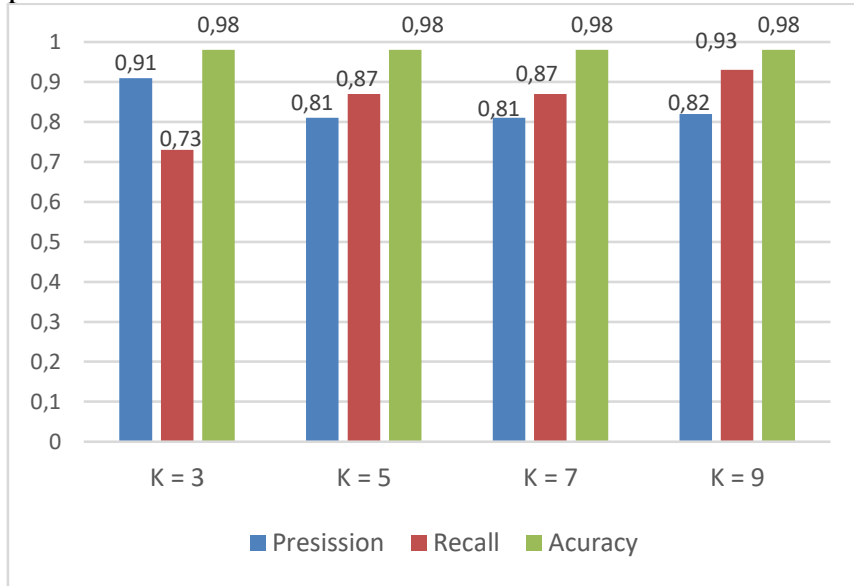

Gambar 16 Grafik Precision, Recall dan Accuracy untuk klasifikasi Gajah

Untuk Panda didapatkan hasil precision yaitu nilai $\mathrm{k}=3$, $\mathrm{k}=5, \mathrm{k}=7$ dan $\mathrm{k}=9$ mendapatkan hasil yaitu 1 . Untuk perhitungan recall nilai tertinggi dicapai oleh $\mathrm{k}=3$ dengan hasil 0,67 dan terendah didapatkan oleh $\mathrm{k}=9$ dengan hasil 0,33 . Untuk accuracy perolehan rata-rata lebih dari 0,9 untuk $\mathrm{k}=3, \mathrm{k}=5, \mathrm{k}=7$, dan $\mathrm{k}=9$. Hasil tersebut bisa dilihat pada Gambar 17.

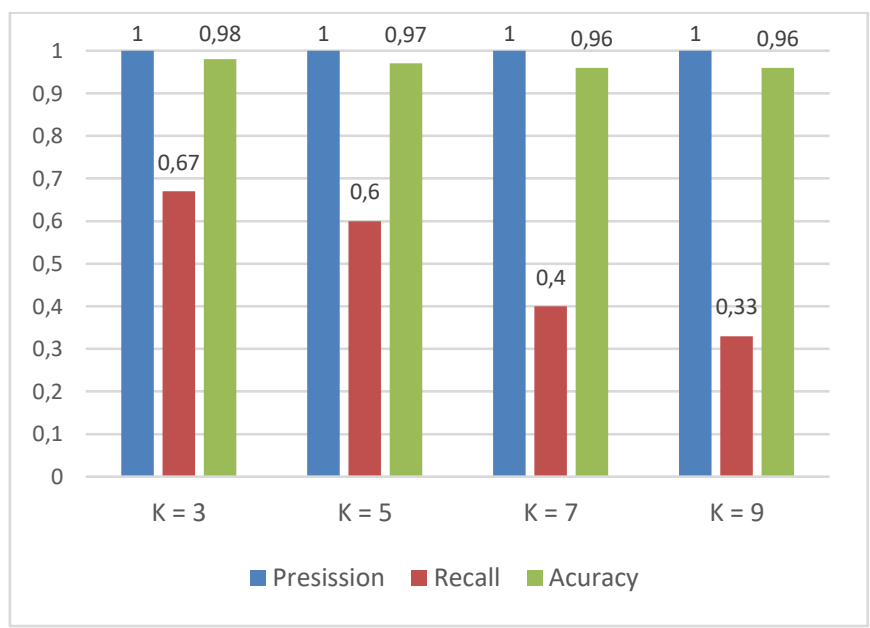

Gambar 17 Grafik Precision, Recall dan Accuracy untuk klasifikasi Panda

Untuk Beruang didapatkan hasil precision yaitu nilai tertinggi diperoleh oleh $\mathrm{k}=3$ dengan perolehan nilai 0,48 untuk nilai terendah didapatkan $\mathrm{k}=7$ dengan perolehan nilai 0,37 . Untuk recall nilai tertinggi dicapai oleh $\mathrm{k}=7$ dan $\mathrm{k}=9$ dengan hasil 1 dan terendah didapatkan oleh $\mathrm{k}=3$ dan $\mathrm{k}=5$ dengan hasil 0,93. Untuk accuracy perolehan rata-rata diatas 0,8 untuk $\mathrm{k}=3, \mathrm{k}=5, \mathrm{k}=7$, dan $\mathrm{k}=9$. Hasil tersebut bisa dilihat pada Gambar 18. 


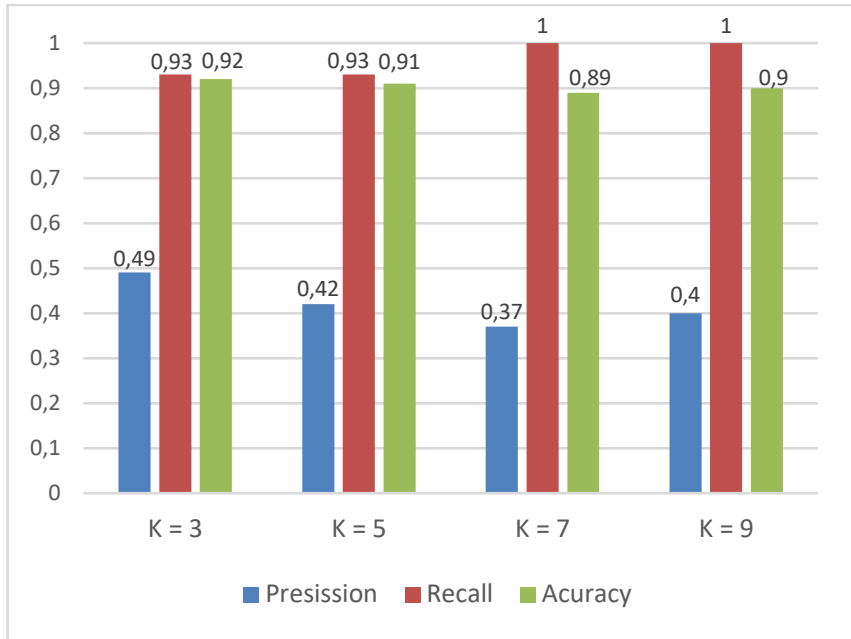

Gambar 18 Grafik Precision, Recall dan Accuracy untuk klasifikasi Beruang

Untuk Kucing didapatkan hasil perhitungan precision yaitu nilai tertinggi diperoleh oleh $\mathrm{k}=3, \mathrm{k}=5$ dan $\mathrm{k}=7$ dengan perolehan nilai 1 , untuk nilai terendah didapatkan $\mathrm{k}=9$ dengan perolehan nilai 0,92 . Untuk recall nilai tertinggi dicapai oleh $\mathrm{k}=5, \mathrm{k}=7$ dan $\mathrm{k}=9$ dengan hasil 0,87 dan terendah didapatkan oleh $\mathrm{k}=3$ dengan hasil 0,8 . Untuk accuracy perolehan rata-rata diatas 0,9 untuk $\mathrm{k}=3, \mathrm{k}=5, \mathrm{k}=7$, dan k=9. Hasil tersebut bisa dilihat pada Gambar 19.

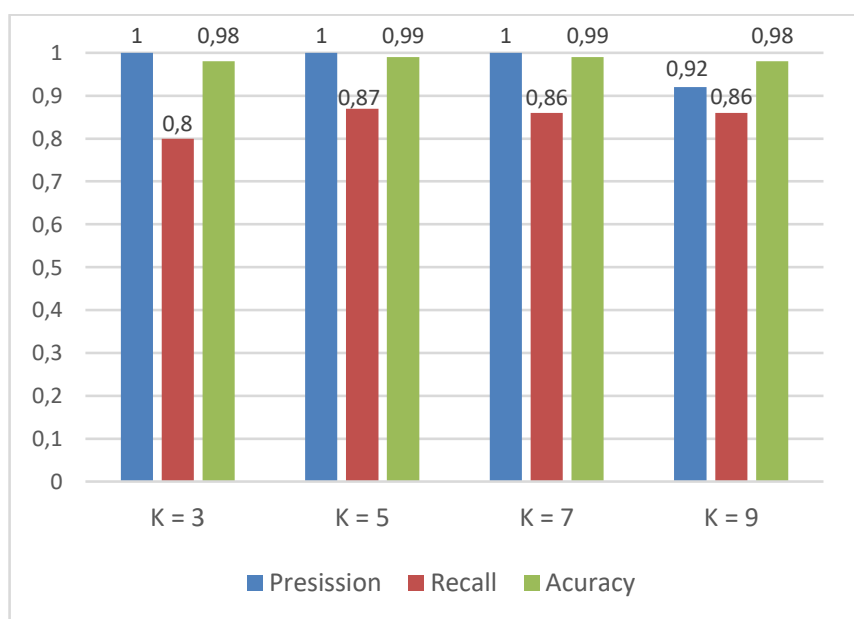

Gambar 19 Grafik Precision, Recall dan Accuracy untuk klasifikasi Kucing

Untuk Anjing didapatkan hasil perhitungan precision yaitu $\mathrm{k}=3, \mathrm{k}=5, \mathrm{k}=7$ dan $\mathrm{k}=9$ dengan perolehan nilai 1 . Untuk recall nilai tertinggi dicapai oleh $\mathrm{k}=5$ dengan hasil 0,2 dan terendah didapatkan oleh $\mathrm{k}=3$ dan $\mathrm{k}=9$ dengan hasil 0,13 . Untuk accuracy perolehan rata-rata diatas 0,9 untuk $\mathrm{k}=3, \mathrm{k}=5, \mathrm{k}=7$, dan $\mathrm{k}=9$. Hasil tersebut bisa dilihat pada Gambar 20.

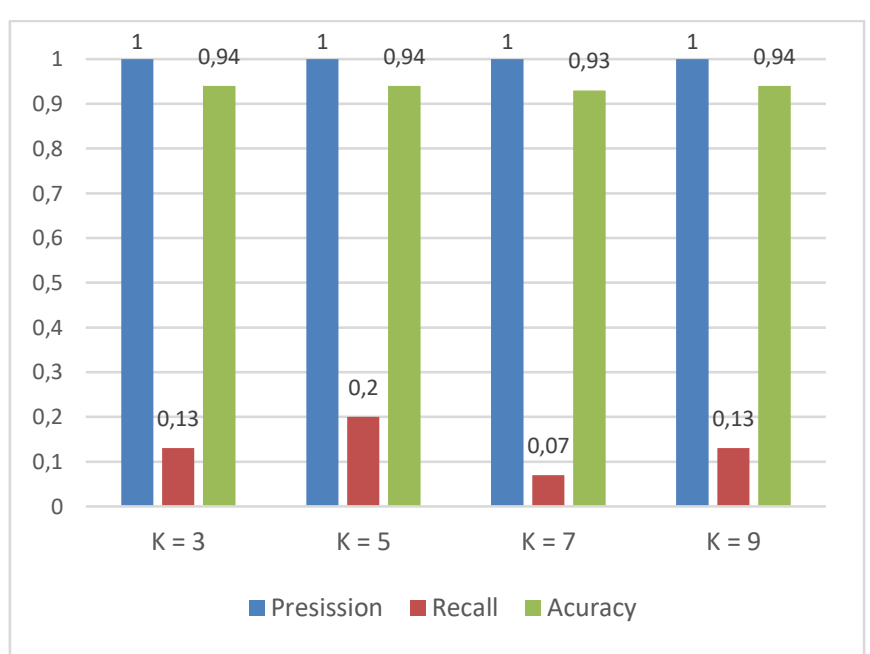

Gambar 20 Grafik Precision, Recall dan Accuracy untuk klasifikasi Anjing

Untuk Singa didapatkan hasil perhitungan precision yaitu nilai tertinggi diperoleh oleh $\mathrm{k}=3$ dengan perolehan nilai 1 , untuk nilai terendah didapatkan $\mathrm{k}=7$ dengan perolehan nilai 0,53 . Untuk recall nilai tertinggi dicapai oleh $\mathrm{k}=9$ dengan hasil 0,6 dan terendah didapatkan oleh $\mathrm{k}=3$ dengan hasil 0,4. Untuk accuracy perolehan rata-rata diatas 0,9 untuk $\mathrm{k}=3$, $\mathrm{k}=5, \mathrm{k}=7$, dan $\mathrm{k}=9$. Hasil tersebut bisa dilihat pada Gambar 21.

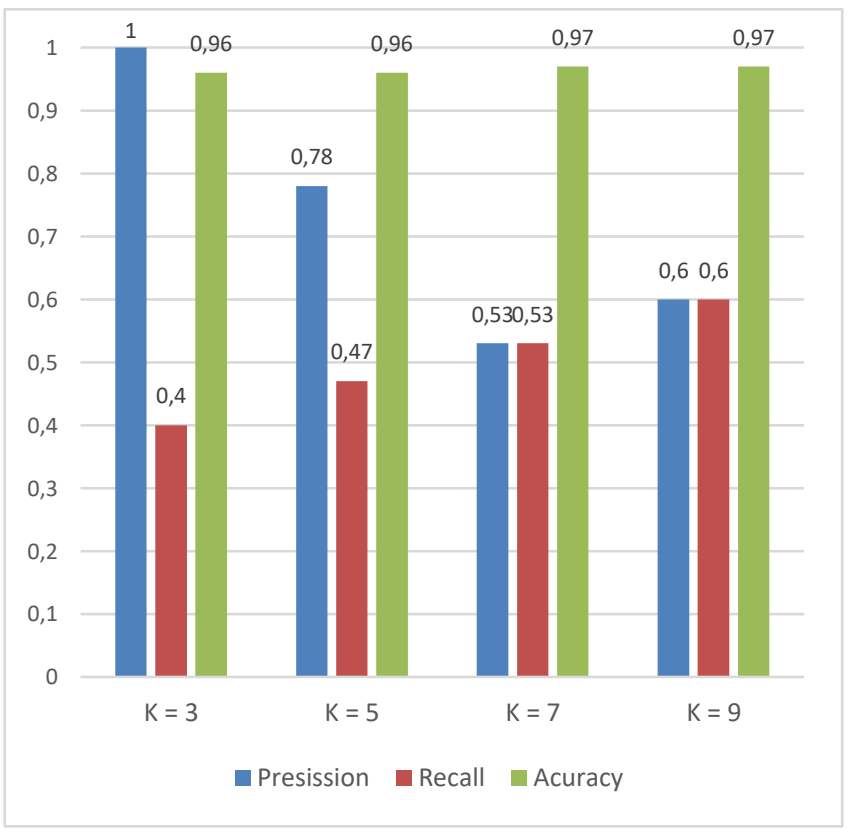

Gambar 21 Grafik Precision, Recall dan Accuracy untuk klasifikasi Singa

Untuk Domba didapatkan hasil perhitungan precision yaitu nilai tertinggi diperoleh oleh $\mathrm{k}=3$ dan $\mathrm{k}=5$ dengan perolehan nilai 1 , untuk nilai terendah didapatkan $\mathrm{k}=7$ dengan perolehan nilai 0,26 . Untuk recall nilai tertinggi dicapai oleh $\mathrm{k}=9$ dengan hasil 0,33 dan terendah didapatkan 
oleh $\mathrm{k}=3, \mathrm{k}=5$ dan $\mathrm{k}=7$ dengan hasil 0,26. Untuk accuracy perolehan rata-rata diatas 0,9 untuk $k=3, k=5, k=7$, dan $k=9$. Hasil tersebut bisa dilihat pada Gambar 22.

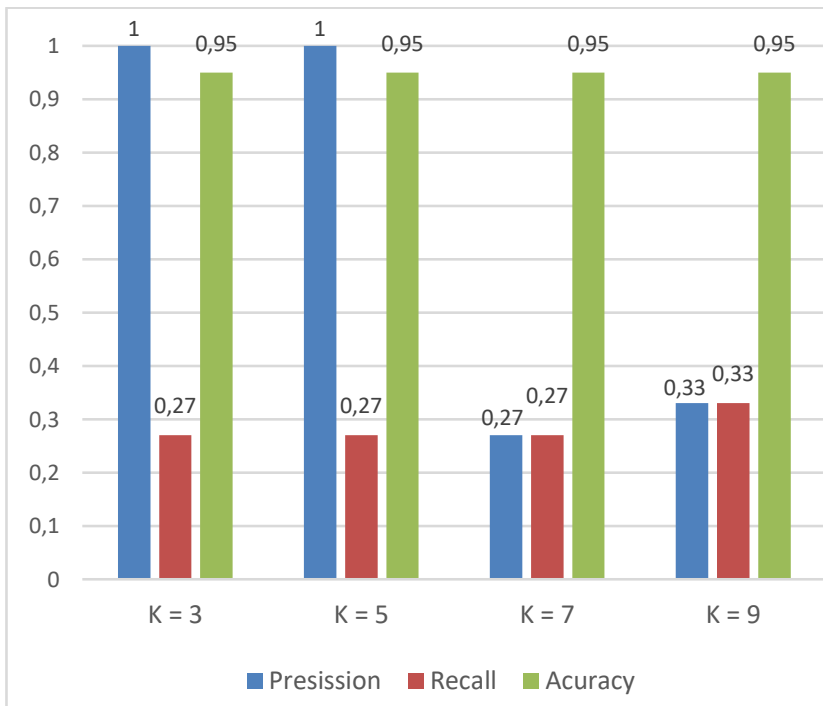

Gambar 22 Grafik Precission, Recall dan Accuracy untuk klasifikasi Domba

\section{Hasil Perhitungan Rata-Rata Precision, Recall,} Accuracy seluruh hewan mamalia.

Dari Tabel V dapat dilihat bahwa rata-rata perhitungan confusion matrix dari semua jenis hewan mamalia untuk setiap $k$ (nilai tetangga terdekatnya). Tabel V menunjukkan bahwa rata-rata tertinggi pada perhitungan precision sebesar 0,794 dan terendah sebesar 0,722 , sedangkan untuk rata-rata tertinggi dan terendah pada recall masing-masing adalah 0,617 dan 0,590. Selanjutnya untuk accuracy rata-rata tertinggi sebesar 0,949 dan terendah sebesar 0,944 .

TABEL V

PRECISION, RECALl, DAN ACCURACY UNTUK KLASIFIKASI WAJAH HEWAN MAMALIA

\begin{tabular}{|c|c|c|c|c|c|c|c|c|c|c|c|c|}
\hline & \multicolumn{4}{|c|}{ Precision } & \multicolumn{4}{|c|}{ Recall } & \multicolumn{4}{|c|}{ Accuracy } \\
\hline & $k=3$ & $k=5$ & $k=7$ & $k=9$ & $k=3$ & $k=5$ & $k=7$ & $k=9$ & $k=3$ & $k=5$ & $k=7$ & $k=9$ \\
\hline Sapi & 0,857 & 0,8 & 0,727 & 0,777 & 0,8 & 0,533 & 0,533 & 0,466 & 0,977 & 0,96 & 0,955 & 0,955 \\
\hline Rusa & 0,517 & 0,5 & 0,466 & 0,483 & 1 & 0,933 & 0,994 & 1 & 0,937 & 0,933 & 0,924 & 0,928 \\
\hline Monyet & 0,283 & 0,291 & 0,318 & 0,304 & 1 & 0,933 & 0,933 & 0,933 & 0,831 & 0,844 & 0,862 & 0,853 \\
\hline Tikus & 0,285 & 0,5 & 0,666 & 0,333 & 0,266 & 0,133 & 0,133 & 0,066 & 0,906 & 0,933 & 0,937 & 0,928 \\
\hline Babi & 1 & 1 & 1 & 1 & 0,133 & 0,2 & 0,133 & 0,133 & 0,942 & 0,946 & 0,942 & 0,942 \\
\hline Kelinci & 0,875 & 0,8 & 0,875 & 1 & 0,466 & 0,533 & 0,466 & 0,4 & 0,96 & 0,96 & 0,96 & 0,96 \\
\hline Macan & 0,916 & 1 & 0,923 & 0,923 & 0,733 & 0,8 & 0,8 & 0,8 & 0,977 & 0,986 & 0,982 & 0,982 \\
\hline Serigala & 0,777 & 0,608 & 0,866 & 0,933 & 0,933 & 0,933 & 0,866 & 0,933 & 0,977 & 0,955 & 0,937 & 0,946 \\
\hline Gajah & 0,916 & 0,812 & 0,812 & 0,823 & 0,733 & 0,866 & 0,867 & 0,933 & 0,977 & 0,977 & 0,977 & 0,982 \\
\hline Panda & 1 & 1 & 1 & 1 & 0,666 & 0,6 & 0,4 & 0,333 & 0,977 & 0,973 & 0,96 & 0,955 \\
\hline Beruang & 0,482 & 0,424 & 0,375 & 0,405 & 0,933 & 0,933 & 1 & 1 & 0,928 & 0,911 & 0,888 & 0,902 \\
\hline Kucing & 1 & 1 & 1 & 0,928 & 0,8 & 0,866 & 0,866 & 0,866 & 0,986 & 0,991 & 0,991 & 0,986 \\
\hline Anjing & 1 & 1 & 1 & 1 & 0,133 & 0,2 & 0,066 & 0,133 & 0,942 & 0,946 & 0,937 & 0,942 \\
\hline Singa & 1 & 0,777 & 0,533 & 0,6 & 0,4 & 0,466 & 0,533 & 0,6 & 0,96 & 0,955 & 0,964 & 0,973 \\
\hline Domba & 1 & 1 & 0,266 & 0,333 & 0,266 & 0,266 & 0,266 & 0,333 & 0,951 & 0,951 & 0,951 & 0,951 \\
\hline Rata-Rata & 0,794 & 0,767 & 0,722 & 0,723 & 0,617 & 0,613 & 0,590 & 0,595 & 0,949 & 0,948 & 0.944 & 0,946 \\
\hline
\end{tabular}




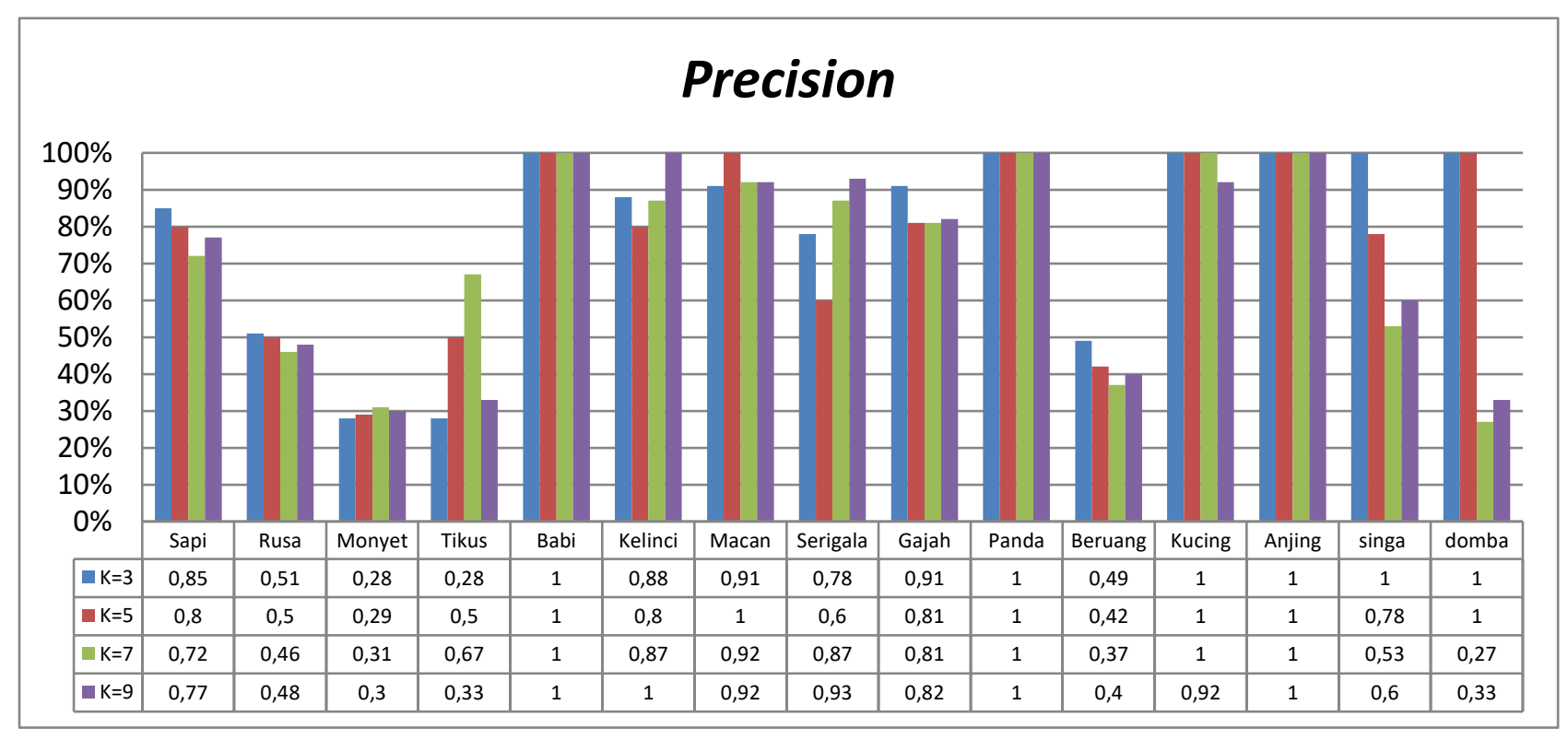

Gambar 23 Grafik Precision Klasifikasi Hewan Mamalia

Gambar 23 menunjukkan hasil perhitungan precision dari semua jenis hewan mamalia pada setiap k-nya. Untuk $\mathrm{k}=3$ memiliki precision $20 \%$ sampai $100 \%, \mathrm{k}=5$ precision mencapai $30 \%$ sampai $100 \%$, $\mathrm{k}=7$ precision $25 \%$ sampai
$100 \%$ sedangkan untuk $\mathrm{k}=9$ precision $30 \%$ sampai $100 \%$. Untuk grafik perhitungan recall dapat dilihat pada Gambar 24.

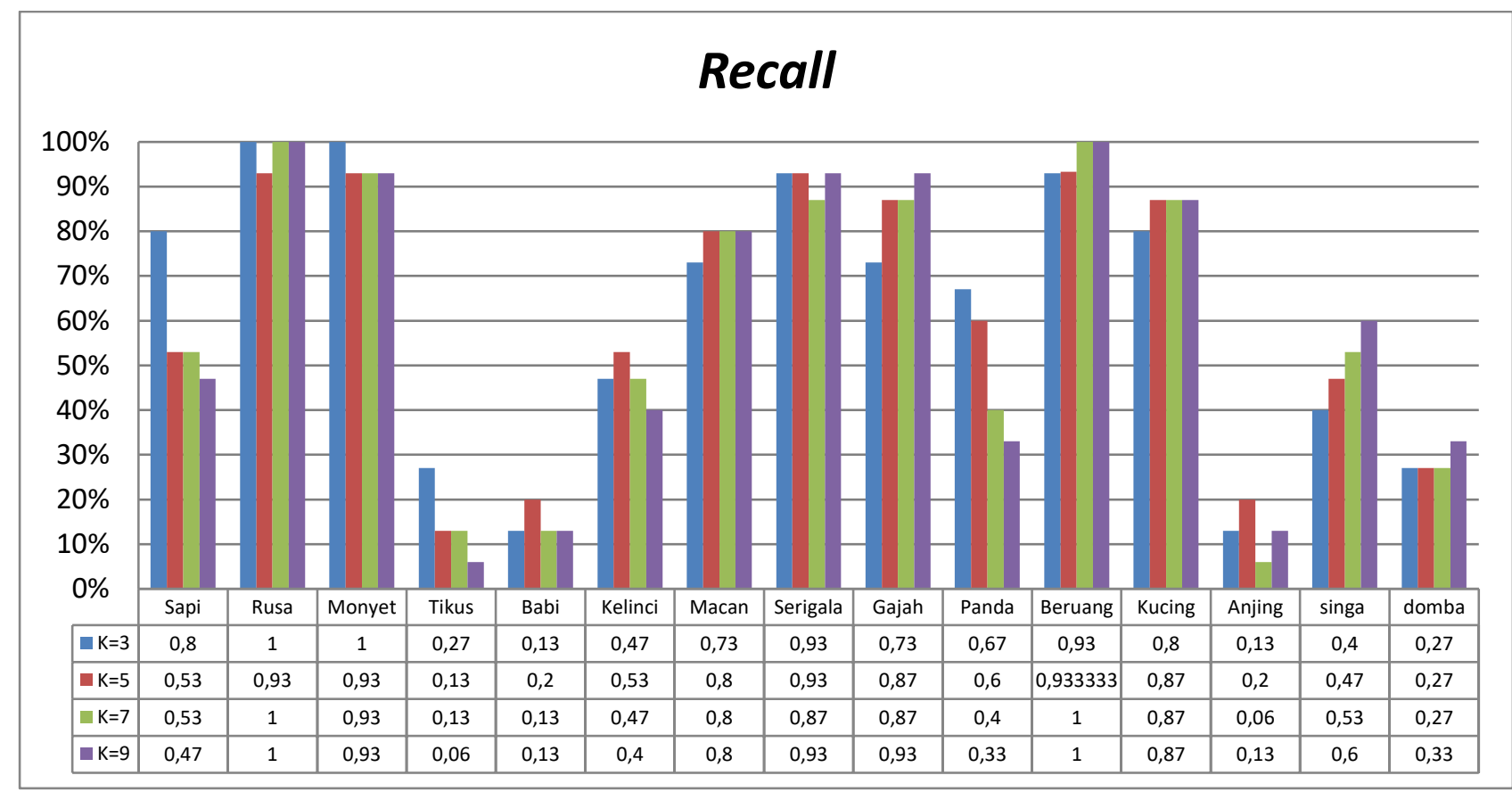

Gambar 24 Grafik Recall Klasifikasi Hewan Mamalia

Gambar 24 menunjukkan hasil perhitungan recall dari semua jenis hewan mamalia pada setiap k-nya. Untuk $\mathrm{k}=3$ memiliki recall $12 \%$ sampai $100 \%, \mathrm{k}=5$ recall mencapai $11 \%$ sampai $100 \%, \mathrm{k}=7$ recall $5 \%$ sampai $100 \%$ sedangkan untuk k=9 recall 5\% sampai $100 \%$. Untuk grafik perhitungan accuracy dapat dilihat pada Gambar 25. 


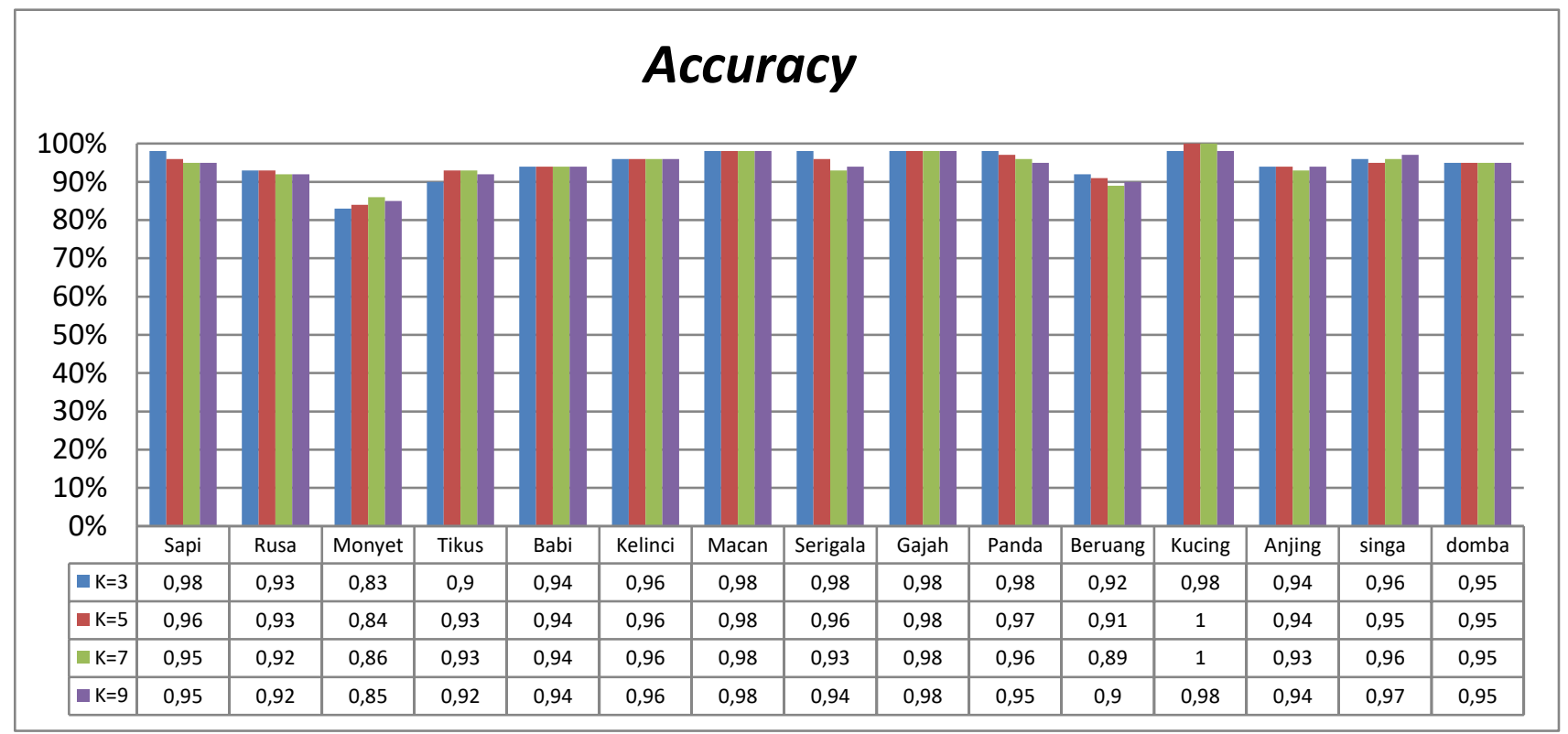

Gambar 25 Grafik Accuracy Klasifikasi Hewan Mamalia

Gambar 25 menunjukkan hasil perhitungan accuracy dari semua jenis hewan mamalia pada setiap $k$-nya. Untuk $\mathrm{k}=3$ memiliki accuracy yang stabil pada setiap jenis hewan mamalia yaitu mencapai $25 \%$ begitu juga untuk $\mathrm{k}=5$ accuracy mencapai $50 \%$ untuk semua jenis hewan mamalia sedangkan untuk $\mathrm{k}=7$ accuracy mengalami penurunan pada jenis hewan monyet tetapi rata-rata accuracy untuk $\mathrm{k}=7$ mencapai $70 \%$ ke atas, sedangkan untuk k=9 accuracy stabil mencapai $100 \%$.

\section{KESIMPULAN}

Berdasarkan hasil pengujian dapat disimpulkan bahwa metode HOG mampu mengekstraksi fitur pada wajah hewan mamalia dengan baik dan metode k-NN mampu mengklasifikasikan wajah hewan mamalia dengan tingkat akurasi yang berbeda untuk setiap $k$-nya. Untuk perhitungan precision, recall, dan accuracy $\mathrm{k}=3$ memiliki tingkat akurasi yang paling baik, dimana hampir semua objek wajah hewan mamalia dapat dikenali dengan baik. Metode k-NN sulit mengenali jenis hewan mamalia Tikus, Babi, Kelinci, Anjing dan Domba, dikarenakan nilai dari feature vector dari hewan mamalia pada saat ekstraksi fitur HOG yang kurang baik.

Untuk proses pengembangan penelitian dalam klasifikasi wajah hewan mamalia tampak depan Sebaiknya menggunakan metode lain untuk klasifikasi wajah hewan mamalia guna meningkatkan tingkat akurasi yang lebih baik. Untuk mendapatkan ekstraksi ciri yang lebih baik sebaiknya bisa menggunakan ekstraksi fitur lain untuk mengenali suatu objek agar meningkatkan tingkat akurasi yang lebih baik
Dengan menggunakan metode $k$-NN dan ekstraksi fitur HOG, klasifikasi jenis hewan mamalia mendapatkan tingkat akurasi yang baik, yaitu mencapai $100 \%$. Perhitungan precision, recall, dan accuracy yang baik, yaitu pada $\mathrm{k}=3$ mendapatkan hasil di atas $50 \%$. Untuk perhitungan precision, recall, dan accuracy yang paling rendah, yaitu pada $\mathrm{k}=7$ rata-rata mendapatkan hasil di bawah $50 \%$.

\section{DAFTAR PUSTAKA}

[1] S. Taheri and Ö. Toygar, "Animal classification using facial images with score-level fusion," IET Comput. Vis., vol. 12, no. 5, pp. 679685, 2018.

[2] F. Fandiansyah, J. Y. Sari, and I. P. Ningrum, "Pengenalan Wajah Menggunakan Metode Linear Discriminant Analysis Dan K Nearest Neighbor," J. Inform., vol. 11, no. 2, pp. 48-59, 2017.

[3] S. D. Cahyaningtyas, "Pengenalan Wajah Menggunakan Metode Ekstraksi Fitur Local Binary Pattern Berdasarkan Metode K-Nearest Neighbor," Tek. Inform. Univ. Dian Nuswantoro, 2016.

[4] F. Liantoni, "Klasifikasi Daun Dengan Perbaikan Fitur Citra Menggunakan Metode K-Nearest Neighbor," J. Ultim., vol. 7, no. 2, pp. 98-104, 2015.

[5] F. Liantoni and H. Nugroho, "Klasifikasi Daun Herbal Menggunakan Metode Naïve Bayes Classifier Dan K- Nearest Neighbor,' J. Simantec, vol. 5, no. 1, pp. 9-16, 2015.

[6] H. Wijayanto, "Klasifikasi Batik Menggunakan Metode K-Nearest Neighbour Berdasarkan Gray Level Co-Occurrence Matrices (GLCM)," Tek. Inform. FIK UDINUS, 2015.

[7] A. Nouvel, "Klasifikasi Kendaraan Roda Empat Berbasis Knn," Bianglala Inform., vol. 3, no. 2, 2015.

[8] S. Subairi, R. Rahmadwati, and E. Yudaningtyas, "Implementasi Metode k-Nearest Neighbor pada Pengenalan Pola Tekstur Citra Saliva untuk Deteksi Ovulasi," EECCIS, vol. 12, no. 1, pp. 9-14, 2018.

[9] N. Hafidhoh and S. E. Sukmana, "Deteksi Pemain Basket 
Terklasifikasi Berbasis Histogram of Oriented Gradients," J. Inf., vol. 3, no. 1, pp. 6-11, 2018.

[10] A. D. Palit, "Mengenali Rambu Lalu Lintas Menggunakan Metode HOG dan KNN," J. Ilm. Teknol. Inf. Terap., vol. III, no. 2, pp. 124 129, 2017.

[11] L. N. Harfiya, A. W. Widodo, and R. C. Wihandika, "Verifikasi Citra Tanda Tangan Berdasarkan Ciri Pyramid Histogram of Oriented Gradient (PHOG) Menggunakan Metode Klasifikasi K-Nearest Neighbor," J. Pengemb. Teknol. Inf. dan Ilmu Komput. Univ. Brawijaya, vol. 1, no. 10, pp. 1162-1171, 2017.

[12] D. Amputri, S. Nadra, G. Gasim, and M. E. Al Rivan, "Perbandingan
Jarak Potret dan Resolusi Kamera pada Tingkat Akurasi Pengenalan Angka kWh Meter Menggunakan SVM," J. Inform. Glob., vol. 8, pp 7-12, 2017.

[13] N. Dalal and B. Triggs, "Histograms of Oriented Gradients for Human Detection," in 2005 IEEE Computer Society Conference on Computer Vision and Pattern Recognition (CVPR'05), 2005, vol. 1, pp. 886-893.

[14] M. E. Al Rivan and Y. Yohannes, "Klasifikasi Mamalia Berdasarkan Bentuk Wajah Dengan K-NN Menggunakan Fitur CAS Dan HOG," J. Tek. Inform. dan Sist. Inf., vol. 5, no. 2, pp. 173-180, 2019. 